\title{
CALL FOR POLICY SHIFT TO HAPPINESS
}

Review of Richard Layard's "Happiness; Lessons from a New Science". New York: The Penguin Press, 2005, ISBN: 1-59420-039-4, 310 pp.

Jan Cornelis Ott

Journal of Happiness Studies (2006) DOI 10.1007/s10902-005-0934-2

Richard Layard is an economist and an expert in unemployment and inequality. He worked for the British government as an economic advisor and in 2000 he became a member of the House of Lords. His ambition is to shift the direction of public policy away from crude economic goals like wealth to "well-being" and "quality of life". Layard advocates an evidence-based utilitarian policy approach and tries to demonstrate how the insights of the new happiness science, in particular positive psychology, can be incorporated in economics in order to develop a new vision of which lifestyles and policies are sensible.

For Layard, happiness is feeling good and wanting to maintain this feeling. Unhappiness is feeling bad and wishing things were different. If people report their feelings, they take a long view and accept ups and downs. Since positive feelings damp down negative feelings and vice versa we may assume that happiness is a onedimensional concept; it is not possible to be happy and unhappy at the same time. Layard rejects - as being paternalistic - the idea of John Stuart Mill to distinguish between types of happiness in terms of higher pleasures, associated with virtuous conduct and philosophical reflection, and lower superficial pleasures. Layard does believe, however, that people who achieve some sense of meaning in life are happier than those who live from one pleasure to the next.

\section{IDENTIFYING THE PROBLEM}

Layard's book consists of two parts; Part 1; "The problem" and Part 2 "What can be done". Layard's problem is that Western people still want more income even though their income has risen considerably in the last 50 years without any substantial increase in average happiness. In explaining this paradox; also formulated by Easterlin in 1974, Layard puts a lot of weight on the effects of social comparison: our wants are not given but depend on what other people have. Social comparison implicates that people who make more money make other people less happy. Additional explanations are the frustration of two basic needs: the need for security and the need for trust in other people.

Layard posits that seven factors affect happiness in adult life; these "big seven" are:

1. Family relationships

2. Financial situation

3. Work

4. Community and friends

5. Health

6. Personal freedom

7. Personal values

The first five factors are given in order of "importance". In the last 50 years the financial situation of people, the quality of work and health have improved but family relationships, the strength and safety of communities and the prevalence of unselfish values have deteriorated.

\section{HAPPINESS AS OUR COMMON GOOD}

After some additional analyses of the causes of this deterioration, like broken families, divorce rates, children born outside marriage, television, increased crime and decreased trust, Layard poses the question whether people need a common good. His answer is positive; people care about their reputation and about social approval by others, they have a sense of fairness and want to make commitments. As a consequence they need a common good or goal as a 
single overarching principle; to solve problems between existing rules, to review rules and to help in situations where rules provide little guidance.

In the first chapter of Part 2 he argues that the greatest happiness should be this single common goal. According to Layard happiness is different from all other goals like health, autonomy, accomplishment and freedom, because it is self-evidently good and not just instrumental in achieving alternative goals. As the American Declaration says: it is a "self-evident" objective. Layard rejects several objections against his utilitarian choice for happiness as the ultimate goal. A well-known objection against the happiness principle is that one innocent person could be killed to set an example for others, with positive effects on average happiness. Layard rejects this objection on the grounds that a happy society has to live by rules, sparing the innocent, telling the truth, keeping promises and so on.

\section{ADAPTATION OF ECONOMICS}

In Chapter 9; "Does economics have a clue?" Layard evaluates the existing economic theory from his utilitarian point of view. Economic theory is correct in his vision in the sense that free markets are indeed very efficient; but only if certain conditions are fulfilled. Layard is concerned in particularly with the importance of "externalities". Externalities are the costs of activities that are not expressed in money, like the happiness cost of the filthy smoke from a mill to the unfortunate neighbors. The mill owner did not take into account such costs when he laid his production plan. To make his plan efficient he should be taxed for such costs. Layard' s key message is that such externalities are pervasive in social life by social comparison: when my colleague is given a raise, this affects me in a negative way even though I am not a party to the exchange. In principle economics can allow for all these interactions to be taken into account, but this the exception in practice. There is a similar systematic failure in costbenefit analysis. In such analyses losses in happiness, as for people who live in a neighborhood where a new highway will be constructed, should be incorporated but this too seldom happens.

To avoid such failures economists should focus less on purchasing power and more on the process of how wellbeing is generated. There are five features to be included in such a new vision:

- Inequality. Extra income matters more to the poor people than to rich.

- External effects. Other people affect us indirectly and not only through exchange.

- Values. Our norms and values change in response to external influences.

- Loss-aversion. We hate loss more than we value gain.

- Inconsistent behavior. We behave inconsistently in many ways.

External effects and changes in values are the two most salient subjects on this list.

\section{EXTERNALITIES}

Layard mentions seven examples of external effects.

- Income. If other people's income increases, I become less satisfied with my own income.

- Work. If my friend receives a performance bonus, I feel I should have one too.

- Family life. If divorce becomes more common, I feel less secure.

- Community. If a transient population moves into my neighborhood, I am more likely to be mugged.

- Health. If more social networks form in my neighborhood, I am less likely to become depressed.

- Freedom. If people cannot speak their mind, I am impoverished.

- Values. If other people become more selfish, my life becomes harder.

This list of examples demonstrates Layard' s broad and social interpretation of the externality-concept. In his vision values are important for happiness, since happiness depends on the gap - or correspondence - between people's wants and people's actual property like cars and bedrooms (p. 139). People's needs depend in their turn on changing values; people get used to what they have and, comparing themselves with other people, they usually adapt their values and want more. These comparisons permanently create bigger or smaller gaps between reality and needs with negative or positive effects on happiness. In this way social comparison by one individual always creates external effects in the interaction between other people; as is demonstrated in Layard's seven examples of external effects.

\section{HOW CAN WE TAME THE RAT RACE?}

In Chapter 10, "How can we tame the rat race?", Layard describes some possibilities to create better conditions for happiness in Western societies. He reformulates and emphasizes again the importance of social comparison by demonstrating the impact of hierarchical status on happiness with statements like the following on p. 150 . 
'We want to entertain other people as well as they entertain us, and we want our children to have the things their friends have. These are not ignoble sentiments of envy; the desire for status is basic to our human nature.'

Money is one of the things that bring status and if money was simply wanted for the sake of status, the quest for money would be totally defeating. The number of ranks in income distribution is fixed, and one person's gain would be another's loss. Fortunately people also want income for its own sake and not only for its value relative to others. At this point Layard refers to a study that found that people care about absolute income twice as much as they care about relative income (Blancheflower and Oswald, 2004), The struggle for relative income is selfdefeating and should be discouraged. A collective agreement would be a solution but there are too many people to make such an agreement possible; we need to find some other way.

Layard has five 'other ways' or principal proposals to tame the rat race.

1. Tax on income from work, or in Layard's words, 'taxing pollution' in order to help people to preserve their work-life balance.

2. Taxing addiction, like a tax on cigarettes, to compensate for the fact that people do not sufficiently anticipate the addictive effects of certain products.

3. Discourage performance related pay because this type of payment stimulates dysfunctional social comparison and undermines intrinsic motivation.

4. Ban commercial advertising directed at children under 12 like in Sweden.

5. Create a better balance between competition and co-operation by stimulating co-operation.

\section{COMMENTS}

Layard's argument is strong and interesting and the following remarks, about his selection of research results and about the logic of his proposals, seem to be appropriate.

\section{Selection of Research Results}

- In his selection of research results, Layard is inspired by his Labor background and in some points his selection is somewhat selective, His list of seven important factors for happiness is not clearly related to empirical research.

- Layard's assessment of the importance of social comparison is not very precise. He admits that people care more about absolute income than about relative income but he still puts a lot of weight on social comparison.

- Layard seems to overestimate this importance of social comparison for happiness. Social comparison is important but cannot really explain differences in happiness within nations and between nations. Differences in objective circumstances like wealth, freedom and institutional developments are more influential. One reason is that people can only compare themselves in a few domains of life like financial situation and work. In important domains of life like community and social relations, marriage, leisure and physical and mental health, such comparison is difficult or even impossible in practice.

- Perhaps as a consequence Layard seems to overestimate the negative effect of income-inequality on happiness. There is no significant correlation between income inequality in nations and inequality in happiness. In rich nations this is probably due to the fact that governments apply income policies, including social security and many transfers and subsidies. This has made the availability of important goods and services, like food, education and medical care, less dependent on personal income (Ott, 2005).

\section{Logic of Proposals}

- In this light Layard's proposal to tax income from work, in order to help people preserve a balance between their work and their life, is somewhat premature and drastic. Premature since income inequality has no substantial negative effect on happiness and too drastic since problems in the balance of work and life are usually rather specific and related to temporal overload. Such problems require more flexibility and individualization in the division of work; this can be achieved by specific policies. The Scandinavian countries and the Netherlands have some interesting legislation in this respect. In the Netherlands employees - men and woman - are for instance entitled to maternity leave, parental leave, emergency leave and adjustment of working times. • Layard's other proposals (2/5) are more convincing. Performance related pay is an old-fashioned carrot-andstick approach; outdated in a modern economy where knowledge has become a key-factor for productivity. Advertising has become a real intrusive nuisance in western societies with negative effects on happiness from stimulating extrinsic motivation and materialism at the expense of intrinsic motivation. 
All in all Layard seems to be a bit too pessimistic about happiness in rich nations. Perhaps the increase in happiness is low compared to the increase in wealth in the last 50 years but we should appreciate - at least! - two facts: the level of happiness in very high? and the relationship between income and happiness has become rather loose. Politicians should cherish this distance between income and happiness and further increase it. In addition to that, happiness probably requires the identification and tackling of specific problems; like work overload, mental problems, performance related pay and advertising. Despite some pessimism and some selectiveness in research interpretation, Layard has made a strong argument in favor of an evidence-based utilitarian policy approach.

\section{REFERENCES}

Blanchflower D., Oswald A. (2004)

Well-being, insecurity and the decline of American job satisfaction,

Well-being over time in Britain and the USA.

Journal of Public Economics 88, pp. 1359-1386.

Ott J.C. (2005)

"Level and inequality of happiness in nations; does greater happiness of a greater number imply greater inequality in happiness?",

Journal of Happiness Studies (2005) 6:397-420, DOI 10.1007/s10902-005-8856-6. 